\title{
Pengaruh Berbagai Kadar Protein dan Energi Ransum pada Pertumbuhan dan Nilai Ekonomis Ayam Sentul-G5 Betina
}

\section{(Effects of Dietary Protein and Energy Levels on the Growth and Economic Value of Females Sentul-G5 Chicken)}

Hidayat C, Iskandar S

Balai Penelitian Ternak, PO Box 221, Ciawi, Bogor 16002

hidayat_c2p@yahoo.com

\begin{abstract}
Sentul-G5 chicken is prepared to be one of the best of pure chicken breed in the local national chicken industry. Therefore, the maximum biological performance information in maintenance with optimum feed supply is needed to know in production efficiency. The aim of this experiment was to determine the effect of levels of dietary protein and energy on the growth and economic efficiency of Sentul-G5 chicken. The experimental design used was a complete randomized design with 6 treatments; R1 (21\% CP, 3,000 kcal ME/kg); R2 (21\% CP, 2,800 kcal ME/kg); R3 (19\% $\mathrm{CP}, 3,000 \mathrm{kcal} \mathrm{ME} / \mathrm{kg}$ ); R4 (19\% CP, 2,800 kcal ME/kg); R5 (17\% CP, 3,000 kcal ME/kg); and R6 $(17 \% \mathrm{CP}, 2,800 \mathrm{kcal} \mathrm{ME} / \mathrm{kg})$. Each treatment was conducted in four replicates, each containing nine days old female chicks. The results showed that Sentul-G5 females up to 15 weeks performed well significantly $(\mathrm{P}<0.05)$ when fed diet of R1 $(21 \% \mathrm{CP}, 3,000 \mathrm{kcal} \mathrm{ME} / \mathrm{kg})$.
\end{abstract}

Key Words: Sentul-G5 Female, Dietary Protein, Dietary Energy

\begin{abstract}
ABSTRAK
Ayam Sentul-G5 dipersiapkan untuk dijadikan salah satu galur unggul murni ayam lokal dalam industri ayam lokal nasional. Oleh karena itu, informasi kinerja biologis maksimum dalam pemeliharaan dengan pasokan pakan optimum perlu diketahui dalam rangka efisiensi produksi. Tujuan dari percobaan ini adalah untuk mengetahui pengaruh berbagai kadar protein dan energi ransum terhadap pertumbuhan dan efisiensi ekonomis ayam Sentul-G5 yang dipelihara sampai umur 15 minggu. Rancangan percobaan yang digunakan adalah rancangan acak lengkap dengan 6 perlakuan; R1 (21\% PK, $3.000 \mathrm{kkal} \mathrm{ME/kg);} \mathrm{R2} \mathrm{(21 \%} \mathrm{PK,} 2.800 \mathrm{kkal} \mathrm{ME/kg);} \mathrm{R3} \mathrm{(19 \%} \mathrm{PK,} 3.000$ kkal ME/kg); R4 (19\% PK, 2.800 kkal ME/kg); R5 (17\% PK, 3.000 kkal ME/kg); dan R6 (17\% $\mathrm{PK}, 2.800 \mathrm{kkal} \mathrm{ME} / \mathrm{kg}$ ). Setiap perlakuan dilengkapi dengan empat kelompok ulangan yang masing-masing berisi sembilan ekor anak ayam Sentul-G5 betina umur satu hari. Hasil percobaan menunjukkan bahwa ayam Sentul-G5 betina sampai umur 15 minggu menunjukkan kinerja nyata $(\mathrm{P}<0,05)$ terbaik ketika diberi perlakuan pakan R1 $(21 \% \mathrm{PK}, 3.000 \mathrm{kkal} \mathrm{ME} / \mathrm{kg})$.
\end{abstract}

Kata Kunci: Sentul-G5 Betina, Protein Ransum, Energi Ransum

\section{PENDAHULUAN}

Ayam Sentul-G5 adalah ayam asli Indonesia berasal dari rumpun Sentul, yang diseleksi untuk pertumbuhan optimum sesuai permintaan pasar, rata-rata bobot hidup $1 \mathrm{~kg}$ per ekor umur 10 minggu (Hasnelly et al. 2011). Ayam Sentul-G5 dipersiapkan untuk dijadikan salah satu galur unggul murni ayam lokal dalam industri ayam lokal nasional. Oleh karena itu, informasi kinerja biologis maksimum dalam pemeliharaan dengan pasokan pakan optimum, perlu diketahui dalam rangka efisiensi produksi.

Peningkatan produktivitas pada ayam Sentul akan diikuti dengan peningkatan kebutuhan gizinya. Rekomendasi kebutuhan gizi dari Sinurat (1991; 1999) masih 
difokuskan untuk ayam-ayam lokal yang belum diseleksi untuk produksi telur atau untuk bobot badan, dengan pemberian energi berkisar antara 2.400-2.600 kkal ME/kg, protein dan $14-15 \%$ protein kasar selama pertumbuhan sampai umur 22 minggu. Sementara itu Iskandar et al. (1998) melaporkan kebutuhan protein kasar mencapai 19\% untuk ayam silangan Pelung-kampung masa pertumbuhan 0-12 minggu.

Hasil percobaan Iskandar et al. (2010) menunjukkan bahwa pertumbuhan ayam lokal hasil pemuliaan Balitnak (ayam KUB) pada ransum dengan protein 17,5\%, energi 2.800 kkal $\mathrm{ME} / \mathrm{kg}$, tidak berbeda nyata $(\mathrm{P}>0,05)$ dengan pertumbuhan pada ransum dengan protein 19, 20 dan 22\%, namun lebih tinggi dari pertumbuhan ayam KUB pada ransum dengan protein $16 \%$. Tingkat protein ransum $17,5 \%$ merupakan tingkat optimum untuk ayam KUB yang diberikan mulai dari day old chick (DOC) sampai umur 22 minggu. Oleh karena itu, formulasi energi ransum dikombinasikan dengan protein ransum kiranya dapat diharapkan untuk mengungkit kapasitas produksi maksimum. Sekaligus dapat memfasilitasi konformiti tubuh yang tinggi, yaitu sekitar $80-90 \%$ bobot badan ayam harus berada pada kisaran $10 \%$ bobot rata-rata populasi, seperti yang disarankan Grieve (2008) pada ayam petelur komersial modern.

Bobot hidup merupakan fungsi dari ukuran sekaligus kondisi fisik seekor ternak (Philip 1970). Lebih jauh lagi selain produksi, good egg-size pada fase awal bertelur akan memberikan suatu keuntungan sebagai telur tetas yang besar, sehingga dapat menghasilkan anak-anak ayam yang lebih besar. Oleh karena itu, pemberian ransum yang tepat kebutuhan diharapkan dapat mengakomodasi pertumbuhan dan produksi telur maksimum. Pemberian ransum tepat dapat menyediakan gizi untuk meningkatkan bobot badan ayam Sentul muda menjelang bertelur untuk menghasilkan telur-telur yang relatif besar. Tujuan dari percobaan ini adalah mengetahui pengaruh berbagai kadar protein dan energi ransum pada pertumbuhan dan efisiensi ekonomis ayam Sentul-G5 yang dipelihara sampai umur 15 minggu.

\section{MATERI DAN METODE}

Sebanyak 216 ekor DOC Sentul-G5 hasil pembiakan di Balai Penelitian Ternak di Ciawi, Bogor dipakai dalam percobaan ini. Rancangan percobaan yang digunakan adalah rancangan acak lengkap dengan enam perlakuan. Adapun pakan perlakuan yang diberikan terdiri dari R1 (21\% protein kasar, PK, 3.000 kkal ME/kg); R2 (21\% PK, 2.800 kkal $\mathrm{ME} / \mathrm{kg}$ ); R3 (19\% PK, $3.000 \mathrm{kkal} \mathrm{ME} / \mathrm{kg}$ ); R4 (19\% PK, $2.800 \mathrm{kkal} \mathrm{ME/kg);} \mathrm{R5} \mathrm{(17 \%} \mathrm{PK,}$ $3.000 \mathrm{kkal} \mathrm{ME} / \mathrm{kg}$ ); dan R6 (17\% PK, $2.800 \mathrm{kkal} \mathrm{ME/kg).} \mathrm{Setiap} \mathrm{perlakuan} \mathrm{dilakukan}$ dengan empat kelompok ulangan yang masing-masing berisi sembilan ekor DOC SentulG5 betina. Percobaan dilaksanakan sampai ayam berumur 15 minggu. Anak-anak ayam dalam setiap ulangan dipelihara dalam sangkar kawat ukuran $60 \times 45 \times 35 \mathrm{~cm}$ yang ditempatkan dalam bangunan beton lengkap dengan penerangan, pemanas dan ventilasi.

Bahan pakan yang akan dipakai dalam percobaan terdiri dari dedak padi kualitas bagus, tepung jagung kualitas bagus, bungkil kedelai dan tepung ikan. Premiks vitamin dan premiks mineral ditambahkan secukupnya sesuai dengan kebutuhan ayam startergrower petelur ras (NRC 1994). Formulasi ransum beserta kadar gizinya disajikan pada Tabel 1. Bahan pakan dibeli sekaligus, setelah diambil sampel dengan gancu dari setiap karung. Ransum kemudian disusun berdasarkan kadar gizi bahan pakan hasil analisis. Ransum yang selesai dicampur dipakai secukupnya secara mingguan dan sisanya disimpan dalam cool room sampai percobaan berakhir. Peubah yang diukur adalah: (1) Bobot hidup; (2) Konsumsi ransum; (3) Efisiensi penggunaan ransum; (4) Analisis ekonomi European 
Tabel 1. Formulasi ransum dan kadar zat gizi pakan percobaan

\begin{tabular}{|c|c|c|c|c|c|c|}
\hline Bahan pakan & $\mathrm{R} 1$ & $\mathrm{R} 2$ & R3 & $\mathrm{R} 4$ & $\mathrm{R} 5$ & R6 \\
\hline Jagung (\%) & 38,65 & 37,65 & 31,00 & 38,00 & 30,6 & 44,00 \\
\hline Dedak padi (\%) & 23,50 & 27,50 & 39,43 & 33,15 & 45,00 & 32,65 \\
\hline Bungkil kedelai (\%) & 30,00 & 23,50 & 20,72 & 14,00 & 13,75 & 6,00 \\
\hline Meat bone meal (\%) & 3,00 & 8,50 & 5,00 & 12,00 & 6,80 & 15,00 \\
\hline Minyak sayur (\%) & 3,00 & 0,50 & 2,00 & 0,50 & 2,00 & 0,50 \\
\hline $\mathrm{CaCO}_{3}$ (kapur) (\%) & 0,70 & 1,20 & 0,70 & 1,20 & 0,70 & 0,70 \\
\hline $\mathrm{NaCl}(\%)$ & 0,50 & 0,50 & 0,50 & 0,50 & 0,50 & 0,50 \\
\hline Vitamin premiks (\%) & 0,15 & 0,15 & 0,15 & 0,15 & 0,15 & 0,15 \\
\hline Mineral premiks (\%) & 0,15 & 0,15 & 0,15 & 0,15 & 0,15 & 0,15 \\
\hline Lysine (\%) & 0,15 & 0,15 & 0,15 & 0,15 & 0,15 & 0,15 \\
\hline Choline clorida $(\%)$ & 0,10 & 0,10 & 0,10 & 0,10 & 0,10 & 0,10 \\
\hline Sodium bikarbonat (\%) & 0,10 & 0,10 & 0,10 & 0,10 & 0,10 & 0,10 \\
\hline Total $(\%)$ & 100 & 100 & 100 & 100 & 100 & 100 \\
\hline \multicolumn{7}{|c|}{ Kadar zat gizi hasil analisis } \\
\hline $\operatorname{Air}(\%)$ & 10,51 & 10,79 & 10,54 & 9,62 & 9,75 & 9,89 \\
\hline ME (kkal ME/kg) & 3.000 & 2.904 & 3.045 & 2.977 & 3.000 & 2.800 \\
\hline Protein $(\%)$ & 21,00 & 22,4 & 19,03 & 18,66 & 17,00 & 17,00 \\
\hline Rasio ME/protein & 144 & 130 & 160 & 160 & 183 & 164 \\
\hline $\mathrm{GE}(\mathrm{kkal} / \mathrm{kg})$ & 4.135 & 4.005 & 4.200 & 4.106 & 4.191 & 3.965 \\
\hline Serat kasar (\%) & 4,04 & 4,42 & 4,79 & 4,38 & 4,28 & 3,73 \\
\hline Abu (\%) & 8,77 & 8,74 & 8,16 & 10,61 & 9,17 & 9,86 \\
\hline Kalsium (\%) & 1,33 & 1,22 & 0,86 & 1,66 & 0,97 & 1,62 \\
\hline Fosfor $(\%)$ & 1,06 & 0,97 & 0,93 & 1,24 & 1,17 & 1,19 \\
\hline \multicolumn{7}{|l|}{ Asam amino } \\
\hline Aspartat (\%) & 2,56 & 2,00 & 2,03 & 1,70 & 1,67 & 1,36 \\
\hline Serine (\%) & 1,04 & 0,85 & 0,87 & 0,86 & 0,74 & 0,68 \\
\hline Glutanine (\%) & 4,29 & 3,38 & 3,41 & 2,94 & 2,83 & 2,57 \\
\hline Glycine (\%) & 1,20 & 1,17 & 1,16 & 1,84 & 1,08 & 1,57 \\
\hline Histidine (\%) & 0,62 & 0,49 & 0,50 & 0,45 & 0,45 & 0,40 \\
\hline Arginine (\%) & 1,67 & 1,4 & 1,40 & 1,37 & 1,23 & 1,26 \\
\hline Threonine (\%) & 0,91 & 0,73 & 0,75 & 0,68 & 0,65 & 0,58 \\
\hline Alanine (\%) & 1,24 & 1,07 & 1,14 & 1,16 & 1,00 & 1,12 \\
\hline Proline (\%) & 1,41 & 1,23 & 1,26 & 1,32 & 1,10 & 1,31 \\
\hline Cysteine (\%) & 0,17 & 0,13 & 0,16 & 0,12 & 0,13 & 0,12 \\
\hline Tyrosine (\%) & 0,67 & 0,56 & 0,55 & 0,55 & 0,46 & 0,44 \\
\hline Valaline (\%) & 1,24 & 0,99 & 1,07 & 0,93 & 0,90 & 0,84 \\
\hline Methionine (\%) & 0,29 & 0,22 & 0,25 & 0,25 & 0,21 & 0,21 \\
\hline Lysine (\%) & 1,57 & 1,25 & 1,34 & 1,09 & 1,07 & 0,85 \\
\hline Isoleucine (\%) & 1,01 & 0,79 & 0,81 & 0,67 & 0,67 & 0,57 \\
\hline Leucine (\%) & 1,97 & 1,57 & 1,66 & 1,43 & 1,41 & 1,33 \\
\hline Phenilalanine (\%) & 1,12 & 0,91 & 0,89 & 0,80 & 0,80 & 0,72 \\
\hline
\end{tabular}


Production Efficiency Factor (EPEF); dan (5) Konsumsi nutrien. Bobot hidup diukur per minggu secara kelompok per unit kandang percobaan, begitu pula konsumsi ransum diukur per minggu secara kelompok per unit kandang percobaan, jumlah konsumsi ransum pada satu unit kandang percobaan dihitung berdasarkan selisih jumlah pemberian dengan sisa pakan yang tersedia pada minggu tersebut. Efisiensi penggunaan pakan dihitung berdasarkan nilai pertambahan bobot hidup (g) selama pengamatan dibagi dengan jumlah konsumsi ransum selama pengamatan (g). Konsumsi nutrien dihitung berdasarkan jumlah konsumsi ransum selama pengamatan dikalikan dengan kandungan gizi (\%) yang terkandung dalam ransum tersebut.

European Production Efficiency Factor dihitung dengan menggunakan rumus berikut (Marcu et al. 2013):

$$
\mathrm{EPEF}=\frac{\text { Viabilitas }(\%) \times \text { bobot hidup }(\mathrm{kg}) \times 100}{\text { Umur }(\text { hari }) \times \mathrm{FCR}}
$$

$\begin{array}{ll}\text { Viabilitas } & =\text { Persen jumlah ayam percobaan yang hidup pada setiap unit percobaan } \\ \text { Bobot hidup } & =\text { Bobot hidup saat pengukuran (g/ekor) } \\ \text { Umur } & =\text { Umur saat pengamatan dihentikan (hari) } \\ \text { FCR } & =\text { Feed conversion ratio }(\mathrm{g} / \mathrm{g})\end{array}$

\section{HASIL DAN PEMBAHASAN}

Pengaruh ransum perlakuan terhadap kinerja ayam Sentul-G5 betina umur 0-15 minggu ditunjukkan pada Tabel 2. Berdasarkan Tabel 2 terlihat bahwa bobot hidup (BH) dan pertambahan bobot hidup (PBH) kelompok ayam Sentul-G5 yang diberi ransum R1 (21\% PK, $3.000 \mathrm{kkal} \mathrm{ME} / \mathrm{kg})$, secara nyata $(\mathrm{P}<0,05)$ menunjukkan nilai $\mathrm{BH}$ dan $\mathrm{PBH}$ tertinggi dibandingkan dengan perlakuan yang lainnya. Hal ini menunjukkan bahwa ayam Sentul-G5 ini, sampai umur 15 minggu menunjukkan pertumbuhan yang responsif secara positif ketika diberi ransum dengan kadar gizi tinggi R1. Di pihak lain, pencapaian BH dan PBH kelompok ayam yang diberi ransum R6, 17\% PK, $2.800 \mathrm{kkal} \mathrm{ME/kg} \mathrm{(ransum} \mathrm{dengan}$ kadar gizi paling rendah), dimana diketahui bahwa tingkat $\mathrm{BH}$ dan $\mathrm{PBH}$ tidak berbeda secara nyata $(\mathrm{P}>0,05)$ dengan kelompok perlakuan $\mathrm{R} 2$ (21\% PK, $2.800 \mathrm{kkal} \mathrm{ME} / \mathrm{kg}), \mathrm{R} 3$ (19\% PK, $3.000 \mathrm{kkal} \mathrm{ME/kg),} \mathrm{R4} \mathrm{(19 \%} \mathrm{PK,} 2.800 \mathrm{kkal} \mathrm{ME/kg),} \mathrm{R5} \mathrm{(17 \%} \mathrm{PK,} 3.000 \mathrm{kkal}$ $\mathrm{ME} / \mathrm{kg}$ ) menunjukkan bahwa ayam Sentul-G5 betina yang dipelihara sampai umur 15 minggu masih menunjukkan kinerja pertumbuhan yang baik ketika diberi ransum dengan kadar gizi rendah (R6, 17\% PK, $2.800 \mathrm{kkal} \mathrm{ME} / \mathrm{kg}$ ). Suatu studi yang dilaporkan oleh Nguyen et al. (2010) bahwa untuk pertumbuhan dan kualitas karkas prima untuk ayam lokal Thailand Bethong memerlukan 19\% protein kasar dengan $3.000 \mathrm{kkal} \mathrm{ME} / \mathrm{kg}$. Pada ayam Sentul-G5 sedikit lebih tinggi akan kebutuhan proteinnya, kemungkinan disebabkan oleh pengaruh seleksi terhadap pertumbuhan, sementara pada ayam Bethong masih merupakan ayam asli (belum terseleksi) tipe pedaging.

Jika dilihat dari rasio energi terhadap proteinnya (Tabel 1), untuk ransum R1 yang memiliki nilai rasio energi terhadap protein 144, diduga superioritas ransum tersebut disebabkan oleh keseimbangan zat gizi protein terhadap energi yang tergambar dari nilai ratio energi terhadap protein pada perlakuan pakan tersebut. Nguyen et al. (2010) melaporkan rasio 158 untuk kadar energi dan protein ransum yang masing-masing 3000 kkal ME/kg dan 19\% merupakan ransum terbaik untuk pertumbuhan ayam lokal Betong (dari Thailand). Sementara itu, ayam lokal Hilly di Bangladesh tumbuh lebih baik pada ransum gizi tinggi $(22 \% \mathrm{PK}, 3.153 \mathrm{kkal} \mathrm{ME} / \mathrm{kg}$, rasio energi terhadap protein 143) (Rahman et al. 2013). 
Seperti ditunjukkan pada Tabel 2, pemberian ransum perlakuan tidak memberikan pengaruh secara nyata $(\mathrm{P}>0,05)$ terhadap tingkat konsumsi ransum ayam Sentul-G5 betina pada umur pemeliharaan 0-15 minggu. Hal ini menunjukkan bahwa aras energi yang digunakan dalam ransum perlakuan (2.800 dan $3.000 \mathrm{kkal} \mathrm{ME} / \mathrm{kg})$ tidak mengakibatkan perbedaan jumlah ransum yang dikonsumsi. Kadar energi merupakan salah satu faktor yang mengakibatkan jumlah konsumsi ransum, dalam rangka mencukupi kebutuhan energinya.

Konversi ransum kelompok ayam yang diberi perlakuan R1 $(21 \%$ PK, 3.000 kkal $\mathrm{ME} / \mathrm{kg})$ secara nyata menunjukkan efisiensi penggunaan pakan paling baik $(\mathrm{P}<0,05)$ dibandingkan dengan perlakuan lainnya. Hal ini menunjukkan bahwa ayam Sentul-G5 menunjukkan efisiensi penggunaan pakan yang tinggi ketika diberi ransum dengan kadar gizi tinggi. Efisiensi penggunaan ransum yang nyata $(\mathrm{P}<0,05)$ lebih baik yang ditunjukkan oleh kelompok R1, dimana pada saat yang sama tingkat konsumsi ransum antar semua perlakuan tidak berbeda nyata $(\mathrm{P}>0,05)$, menunjukkan bahwa konversi ransum menjadi daging yang dilakukan oleh kelompok ayam yang diberi perlakuan R1, secara nyata $(\mathrm{P}<0,05)$ lebih baik/efisien dibandingkan dengan kelompok ayam yang diberi perlakuan lain.

Sementara itu, persentase viabilitas ayam Sentul-G5 tidak dipengaruhi $(\mathrm{P}>0,05)$ oleh ransum perlakuan. Hal ini menunjukkan bahwa kadar gizi, khususnya protein dan energi yang digunakan dalam percobaan tidak mengakibatkan kematian selama masa percobaan sampai umur 15 minggu. Efisiensi kinerja yang dilihat dari nilai EPEF yaitu salah satu nilai yang juga dapat dipakai sebagai acuan untuk menentukan kelompok perlakuan ransum mana yang paling efisien (Samarakoon \& Samarasinghe 2012; Marcu et al. 2013). EPEF ini selain memperhitungkan bobot hidup dan FCR, juga memperhitungkan lama pemeliharaan ternak. Nilai EPEF tertinggi adalah nilai terbaik, semakin besar nilai EPEF semakin baik usaha. Pada Tabel 2, dapat dilihat bahwa efisiensi kinerja yang dilihat dari nilai EPEF diketahui bahwa kelompok ayam yang diberi perlakuan R1 (21\% PK, 3.000 kkal $\mathrm{ME} / \mathrm{kg}$ ), secara nyata $(\mathrm{P}<0,05)$ menunjukkan nlai EPEF paling tinggi (385) dibandingkan dengan perlakuan lainnya. Hal ini menunjukkan bahwa kelompok ayam yang diberi perlakuan R1 menunjukkan efisiensi terbaik $(\mathrm{P}<0,05)$ secara ekonomi dibanding kelompok ayam yang diberi perlakuan lainnya. Hal ini mengindikasikan bahwa pemberian perlakuan R1 memberikan pengaruh terbaik terhadap capaian efisiensi penggunaan pakan dan efisiensi ekonomis pada pemiliharaan ayam Sentul-G5 pada pemeliharaan sampai umur 15 minggu.

Pengaruh ransum perlakuan terhadap konsumsi nutrien (PK, GE, ME, Ca dan P) dan asam amino ayam Sentul-G5 betina umur 0-15 minggu ditunjukkan pada Tabel 3. Beradasarkan Tabel 3 terlihat bahwa kelompok perlakuan R1 dan R2 menunjukkan konsumsi protein paling tinggi $(\mathrm{P}<0,05)$ dibandingkan dengan perlakuan lainnya. Kisaran konsumsi protein kasar selama 15 minggu pemeliharaan adalah 735 sampai 1.001 g/ekor. Sementara itu, konsumsi energi (GE dan ME) tampak tidak dipengaruhi $(\mathrm{P}>0,05)$ oleh perlakuan. Kisaran konsumsi GE selama 15 minggu pemeliharaan adalah 17.755 sampai $18.888 \mathrm{kkal}$. Sementara itu, kisaran konsumsi ME selama 15 minggu pemeliharaan adalah 12.872 sampai 13.694 kkal ME. Konsumsi kalsium dan fosfor paling tinggi terjadi pada R4 dan R6 dengan kisaran konsumsi kalsium tertinggi selama 15 minggu pemeliharaan adalah 72,54-74,70 g/ekor, sedangkan kisaran konsumsi fosfor tertinggi selama 15 minggu pemeliharaan adalah 53,28-55,80 g/ekor. Nilai konsumsi gizi merupakan hasil perkalian dari kadar nutrien tersebut yang terkandung dalam pakan perlakuan yang dikalikan dengan jumlah konsumsi ransum selama masa percobaan. Sehingga nilai konsumsi nutrient sangat ditentukan oleh kadar nutrient tersebut dan jumlah konsumsi pakan perlakuan selama masa percobaan. 
Tabel 2. Bobot hidup (BH), pertambahan bobot hidup (PBH), konsumsi ransum (KR), efisiensi pengggunaan pakan (FCR), viabilitas dan EPEF ayam SentulG5 betina umur 0-15 minggu yang diberi ransum perlakuan

\begin{tabular}{|c|c|c|c|c|c|c|c|c|c|c|c|c|}
\hline \multirow{2}{*}{ Peubah } & \multicolumn{2}{|c|}{ R1 } & \multicolumn{2}{|c|}{ R2 } & \multicolumn{2}{|c|}{ R3 } & \multicolumn{2}{|c|}{ R4 } & \multicolumn{2}{|c|}{ R5 } & \multicolumn{2}{|c|}{ R6 } \\
\hline & Rata-rata & SD & Rata-rata & $\mathrm{SD}$ & Rata-rata & $\mathrm{SD}$ & Rata-rata & $\mathrm{SD}$ & Rata-rata & SD & Rata-rata & SD \\
\hline BH (g/ekor) & $1.374^{\mathrm{b}}$ & 108 & $1.245^{\mathrm{a}}$ & 70 & $1.239^{\mathrm{a}}$ & 45 & $1.237^{\mathrm{a}}$ & 50 & $1.202^{\mathrm{a}}$ & 48 & $1.238^{\mathrm{a}}$ & 67 \\
\hline PBH (g/ekor) & $1.345^{\mathrm{b}}$ & 109 & $1.215^{\mathrm{a}}$ & 69 & $1.210^{\mathrm{a}}$ & 45 & $1.208^{\mathrm{a}}$ & 49 & $1.172^{\mathrm{a}}$ & 48 & $1.208^{\mathrm{a}}$ & 68 \\
\hline KR (g/ekor) & $4.568^{\mathrm{a}}$ & 197 & $4.469^{\mathrm{a}}$ & 288 & $4.391^{\mathrm{a}}$ & 112 & $4.500^{\mathrm{a}}$ & 281 & $4.425^{\mathrm{a}}$ & 124 & $4.478^{\mathrm{a}}$ & 175 \\
\hline FCR & $3,40^{\mathrm{a}}$ & 0,14 & $3,67^{\mathrm{b}}$ & 0,04 & $3,62^{b}$ & 0,06 & $3,72^{\mathrm{b}}$ & 0,13 & $3,77^{\mathrm{b}}$ & 0,19 & $3,70^{\mathrm{b}}$ & 0,17 \\
\hline Viabilitas (\%) & $100^{\mathrm{a}}$ & 0,00 & $94,44^{\mathrm{a}}$ & 6,42 & $100^{\mathrm{a}}$ & 0,00 & $94,44^{\mathrm{a}}$ & 6,42 & $97,22^{\mathrm{a}}$ & 5,56 & $100^{\mathrm{a}}$ & 0,00 \\
\hline EPEF & $385^{\mathrm{b}}$ & 46 & $303^{\mathrm{a}}$ & 12 & $325^{\mathrm{a}}$ & 16 & $299^{a}$ & 25 & $295^{\mathrm{a}}$ & 27 & $318^{\mathrm{a}}$ & 29 \\
\hline
\end{tabular}

SD: Standar deviasi; Superskrip yang berbeda pada baris yang sama menunjukkan berbeda nyata $(\mathrm{P}<0,05)$ 
Tabel 3. Konsumsi nutrien ( $\mathrm{PK}, \mathrm{GE}, \mathrm{ME}, \mathrm{Ca}, \mathrm{P}$ ) dan konsumsi asam amino ayam Sentul-G5 betina umur 0-15 minggu yang diberi ransum perlakuan

\begin{tabular}{|c|c|c|c|c|c|c|c|c|c|c|c|c|}
\hline \multirow{2}{*}{ Peubah } & \multicolumn{2}{|c|}{$\mathrm{R} 1$} & \multicolumn{2}{|c|}{$\mathrm{R} 2$} & \multicolumn{2}{|c|}{ R3 } & \multicolumn{2}{|c|}{$\mathrm{R} 4$} & \multicolumn{2}{|c|}{$\mathrm{R} 5$} & \multicolumn{2}{|c|}{ R6 } \\
\hline & Rata-rata & SD & Rata-rata & SD & Rata-rata & SD & Rata-rata & SD & Rata-rata & SD & Rata-rata & SD \\
\hline PK (g/ekor) & $949^{c}$ & 41,02 & $1.001^{\mathrm{c}}$ & 64,61 & $835^{\mathrm{b}}$ & 21,25 & $839^{\mathrm{b}}$ & 52,51 & $735^{\mathrm{a}}$ & 20,66 & $783^{\mathrm{ab}}$ & 30,55 \\
\hline GE (kkal/ekor) & $18.888^{\mathrm{a}}$ & 816 & $17.900^{\mathrm{a}}$ & 11.553 & $18.444^{\mathrm{a}}$ & 469 & $18.479^{\mathrm{a}}$ & 1.155 & $18.546^{\mathrm{a}}$ & 521 & $17.755^{\mathrm{a}}$ & 693 \\
\hline ME (kkal ME/ekor) & $13.694^{\mathrm{a}}$ & 592 & $12.977^{\mathrm{a}}$ & 837 & $13.371^{\mathrm{a}}$ & 340 & $13.397^{\mathrm{a}}$ & 838 & $13.446^{\mathrm{a}}$ & 378 & $12.872^{\mathrm{a}}$ & 502 \\
\hline $\mathrm{Ca}$ (g/ekor) & $60,75^{\mathrm{d}}$ & 2,63 & $54,52^{\mathrm{c}}$ & 3,52 & $37,76^{\mathrm{a}}$ & 0,96 & $74,70^{\mathrm{e}}$ & 4,67 & $42,92^{\mathrm{b}}$ & 1,21 & $72,54^{\mathrm{e}}$ & 2,83 \\
\hline $\mathrm{P}$ (g/ekor) & $48,42^{\mathrm{b}}$ & 2,09 & $43,35^{\mathrm{a}}$ & 2,80 & $40,84^{\mathrm{a}}$ & 1,04 & $55,80^{\mathrm{d}}$ & 3,49 & $51,77^{\mathrm{bc}}$ & 1,45 & $53,28^{\mathrm{cd}}$ & 2,08 \\
\hline \multicolumn{13}{|l|}{ Asam amino (g/ekor) } \\
\hline Asp & $116,94^{\mathrm{d}}$ & 5,05 & $89,39^{c}$ & 5,77 & $89,14^{\mathrm{c}}$ & 2,27 & $76,50^{\mathrm{b}}$ & 4,78 & $73,90^{\mathrm{b}}$ & 2,08 & $60,90^{\mathrm{a}}$ & 2,38 \\
\hline Ser & $47,50^{c}$ & 2,05 & $37,99^{\mathrm{b}}$ & 2,45 & $38,20^{\mathrm{b}}$ & 0,97 & $38,70^{\mathrm{b}}$ & 2,42 & $32,74^{\mathrm{a}}$ & 0,92 & $30,45^{\mathrm{a}}$ & 1,19 \\
\hline Glu & $195,96^{\mathrm{d}}$ & 8,47 & $151,07^{\mathrm{c}}$ & 9,75 & $149,74^{\mathrm{c}}$ & 3,81 & $132,31^{\mathrm{b}}$ & 8,27 & $125,23^{\mathrm{ab}}$ & 3,52 & $115,08^{\mathrm{a}}$ & 4,49 \\
\hline Gly & $54,81^{\mathrm{b}}$ & 2,37 & $52,29^{\mathrm{ab}}$ & 3,37 & $50,94^{\mathrm{ab}}$ & 1,30 & $82,81^{\mathrm{d}}$ & 5,18 & $47,79^{\mathrm{a}}$ & 1,34 & $70,30^{c}$ & 2,74 \\
\hline His & $28,32^{\mathrm{d}}$ & 1,22 & $21,90^{\mathrm{c}}$ & 1,41 & $21,95^{\mathrm{c}}$ & 0,56 & $20,25^{\mathrm{b}}$ & 1,27 & $19,91^{\mathrm{b}}$ & 0,56 & $17,91^{\mathrm{a}}$ & 0,70 \\
\hline Arg & $76,28^{\mathrm{c}}$ & 3,30 & $62,57^{\mathrm{b}}$ & 4,04 & $61,48^{\mathrm{b}}$ & 1,56 & $61,65^{\mathrm{b}}$ & 3,86 & $54,43^{\mathrm{a}}$ & 1,53 & $56,42^{\mathrm{a}}$ & 2,20 \\
\hline Thr & $41,56^{\mathrm{d}}$ & 1,80 & $32,62^{c}$ & 2,11 & $32,93^{c}$ & 0,84 & $30,60^{\mathrm{bc}}$ & 1,91 & $28,76^{\mathrm{b}}$ & 0,81 & $25,97^{\mathrm{a}}$ & 1,01 \\
\hline Ala & $56,64^{\mathrm{d}}$ & 2,45 & $47,82^{\mathrm{b}}$ & 3,09 & $50,06^{\mathrm{bc}}$ & 1,27 & $52,20^{c}$ & 3,26 & $44,25^{\mathrm{a}}$ & 1,24 & $50,15^{\mathrm{bc}}$ & 1,96 \\
\hline Pro & $64,40^{\mathrm{d}}$ & 2,78 & $54,97^{\mathrm{b}}$ & 3,55 & $55,33^{b c}$ & 1,41 & $59,40^{c}$ & 3,71 & $48,67^{\mathrm{a}}$ & 1,37 & $58,66^{\text {bc }}$ & 2,29 \\
\hline Cys & $7,76^{\mathrm{c}}$ & 0,34 & $5,81^{\mathrm{a}}$ & 0,37 & $7,02^{\mathrm{b}}$ & 0,18 & $5,40^{\mathrm{a}}$ & 0,34 & $5,75^{\mathrm{a}}$ & 0,16 & $5,37^{\mathrm{a}}$ & 0,21 \\
\hline Tyr & $30,60^{c}$ & 1,32 & $25,02^{\mathrm{b}}$ & 1,62 & $24,15^{\mathrm{b}}$ & 0,61 & $24,75^{\mathrm{b}}$ & 1,55 & $20,35^{\mathrm{a}}$ & 0,57 & $19,70^{\mathrm{a}}$ & 0,77 \\
\hline Val & $56,64^{\mathrm{e}}$ & 2,45 & $44,24^{\mathrm{cd}}$ & 2,86 & $46,98^{\mathrm{d}}$ & 1,19 & $41,85^{\mathrm{bc}}$ & 2,62 & $39,82^{\mathrm{ab}}$ & 1,12 & $37,61^{\mathrm{a}}$ & 1,47 \\
\hline Met & $13,24^{\mathrm{c}}$ & 0,57 & $9,83^{\mathrm{a}}$ & 0,63 & $10,97^{b}$ & 0,28 & $11,25^{\mathrm{b}}$ & 0,70 & $9,29^{\mathrm{a}}$ & 0,26 & $9,40^{\mathrm{a}}$ & 0,37 \\
\hline Lys & $71,71^{\mathrm{d}}$ & 3,10 & $55,86^{\mathrm{c}}$ & 3,61 & $58,84^{\mathrm{c}}$ & 1,50 & $49,05^{b}$ & 3,07 & $47,35^{\mathrm{b}}$ & 1,33 & $38,06^{\mathrm{a}}$ & 1,48 \\
\hline Ile & $46,13^{\mathrm{d}}$ & 1,99 & $35,30^{c}$ & 2,28 & $35,57^{\mathrm{c}}$ & 0,90 & $30,15^{\mathrm{b}}$ & 1,89 & $29,64^{\mathrm{b}}$ & 0,83 & $25,52^{\mathrm{a}}$ & 1,00 \\
\hline Leu & $89,98^{c}$ & 3,89 & $70,17^{\mathrm{b}}$ & 4,53 & $72,89^{\mathrm{b}}$ & 1,85 & $64,35^{\mathrm{a}}$ & 4,02 & $62,396^{a}$ & 1,75 & $59,55^{\mathrm{a}}$ & 2,32 \\
\hline Phe & $51,16^{\mathrm{d}}$ & 2,21 & $40,67^{c}$ & 2,62 & $39,08^{c}$ & 0,99 & $36,01^{b}$ & 2,25 & $35,40^{\mathrm{b}}$ & 0,99 & $32,24^{\mathrm{a}}$ & 1,26 \\
\hline
\end{tabular}

SD: Standar deviasi; Superskrip yang berbeda pada baris yang sama menunjukkan berbeda nyata $(\mathrm{P}<0,05)$ 
Pengaruh ransum perlakuan pada konsumsi asam amino ayam Sentul-G5 betina umur 0-15 minggu ditunjukkan pada Tabel 3. Berdasarkan tabel tersebut di atas terlihat bahwa secara keseluruhan, kelompok perlakuan $\mathrm{R} 1$ secara nyata $(\mathrm{P}<0,05)$ menunjukkan tingkat konsumsi asam amino paling tinggi dibandingkan dengan perlakuan lainnya kecuali asam amino glisin yang tinggi pada R4. Hal ini terkait dengan kadar asam amino yang terkandung dalam pakan perlakuan R1 dan jumlah konsumsi ransum perlakuan untuk pakan perlakuan R1 selama masa percobaan (0-15 minggu).

\section{KESIMPULAN}

Ayam Sentul-G5 betina menunjukan laju pertumbuhan dengan tingkat efisiensi penggunaan pakan dan efisiensi ekonomis terbaik pada pemeliharaan sampai umur 15 minggu ketika diberi perlakuan pakan dengan kadar gizi 21\% protein kasar dengan 3.000 $\mathrm{kal} \mathrm{ME} / \mathrm{kg}$. Sehingga ransum dengan kadar gizi tersebut direkomendasikan diberikan pada ayam Sentul-G5 betina sampai umur 15 minggu.

\section{UCAPAN TERIMA KASIH}

Terima kasih kami ucapkan kepada karyawan/karywati pelaksana kandang ayam, Balai Penelitian Ternak, Ciawi, Bogor yang dengan tekun membantu penyelesaian percobaan ini. Begitu juga kepada karyawan/karyawati di bagian perencanaan, kebendaharaan, pengadaan dan pelaporan, kami mengucapkan terima kasih atas segala dukungan fasilitas dalam kelancaran penyelesaian percobaan ini.

\section{DAFTAR PUSTAKA}

Grieve D. 2008. Enhancing early egg size and maintaining shell quality in layers [Internet]. Available from: http://www1.agric.gov.ab.ca/\$department/deptdocs.nsf/all/pou3651?open document

Hasnelly Z, Sartika T, Zainuddin D, Komaruddin. 2011. Persilangan pada ayam lokal (KUB, Sentul, Gaok) untuk meningkatkan produksi daging unggas nasional. Dalam: Iskandar S, Resnawati H, Priyantini A, Sartika T, Damayanti R, penyunting. Prosiding Workshop Nasional Unggas Lokal. Bogor (Indonesia): Puslitbangnak. hlm. 102-108.

Iskandar S, Zainuddin D, Sastrodihardjo S, Sartika T, Setiadi P, Susanti T. 1998. Respon pertumbuhan ayam Kampung dan ayam silangan Pelung terhadap ransum berbeda kadar protein. JITV. 3:8-14.

Iskandar S, Sartika T, Hidayat C, Kadiran. 2010. Penentuan kebutuhan protein kasar ransum ayam Kampung Unggul Balitnak (KUB) masa pertumbuhan (0-22 minggu). Laporan Penelitian TA 2009. Bogor (Indonesia): Balai Penelitian Ternak.

Marcu A, Opris IV, Domitrescu G, Ciochina LP, Marcu A, Nicula M, Pet I, Dronca D, Kelcio B, Maris C. 2013. The influence of genetics on economic efficiency of broiler chickens growth. Anim Sci Biotechnol. 46:339-346.

Nguyen TV, Bunchasak C, Chantsavang S. 2010. Effect of dietary protein and energy on growth performance and carcass characteristic of Betong chicken (Gallus domesticus) during growing period. Int J Poult Sci. 9:468-472.

NRC. 1994. Nutrient requirement for poultry. New York (US): National Research Council, National Academic Sciences. 
Philip JS. 1970. Poultry feeds and nutrition. New York (US): The Avi Publishing Co Inc. West Port Connection.

Rahman MM, Faruque S, Islam MS, Islam MN, Rashid MA. 2013. Comparison of growth performance and meat yield of hilly chicken under two feeding regimes. Agriculturists. 11:3843.

Samarakoon SMR, Samarasnghe K. 2012. Strategies to improve the cost effectiveness of broiler production. Trop Agric Res. 23:338-346.

Sinurat AP. 1991. Penyusunan ransum ayam buras. Wartazoa. 2:1-4.

Sinurat AP. 1999. Penggunaan bahan pakan lokal dalam pembuatan ransum ayam buras. Wartazoa, 9:12-20. 